\title{
Whole Genome Resources of 17 Curtobacterium flaccumfaciens Strains Including Pathotypes of C. flaccumfaciens pv. betae, C. flaccumfaciens pv. oortii, and C. flaccumfaciens pv. poinsettiae
}

\author{
Ebrahim Osdaghi, ${ }^{1, \dagger}$ Geraldine Taghouti, ${ }^{2}$ Cecile Dutrieux, ${ }^{2}$ S. Mohsen Taghavi, ${ }^{3}$ \\ Amal Fazliarab, ${ }^{4}$ Martial Briand, ${ }^{2}$ Marion Fischer-Le Saux, ${ }^{2}$ Perrine Portier, ${ }^{2, \dagger}$ and \\ Marie-Agnes Jacques ${ }^{2, \dagger}$ \\ ${ }^{1}$ Department of Plant Protection, College of Agriculture, University of Tehran, Karaj 31587-77871, Iran \\ ${ }^{2}$ University of Angers, Institut Agro, INRAE, IRHS, SFR QUASAV, CIRM-CFBP, F-49000 Angers, \\ France \\ ${ }^{3}$ Department of Plant Protection, School of Agriculture, Shiraz University, Shiraz 71441-65186, Iran \\ ${ }^{4}$ Iranian Sugarcane Research and Training Institute (ISCRTI), Ahvaz, Khuzestan, Iran
}

Curtobacterium flaccumfaciens complex species in the family Microbacteriaceae encompasses a group of plant-pathogenic actinobacterial strains affecting annual crops and ornamental plants. The species includes five pathovars, namely $C$. flaccumfaciens pv. betae, C. flaccumfaciens pv. flaccumfaciens, C. flaccumfaciens pv. ilicis, C. flaccumfaciens pv. oortii, and C. flaccumfaciens pv. poinsettiae. Despite the economic importance of C. flaccumfaciens, its members have rarely been investigated for their phylogenetic relationships, molecular characteristics, and virulence repertories, due, in part, to the lack of wholegenome resources. Here, we present the whole-genome sequence of $17 \mathrm{C}$. flaccumfaciens strains representing members of four pathovars isolated from different plant species in a diverse geographical and temporal span. The genomic data presented in this study will pave the way for research on the comparative genomics, phylogenomics, and taxonomy of $C$. flaccumfaciens and extend our understanding of the virulence features of the species.

Gram-positive actinobacterial plant pathogens in the family Microbacteriaceae comprise a series of economically important agents infecting several annual crops, ornamental plants, and vegetables (Dye and Kemp 1977; Jacques et al. 2012). Plant-pathogenic members in this group include Clavibacter spp., Rathayibacter spp., Leifsonia xyli, and Curtobacterium flaccumfaciens (Vidaver and Davis 1988). The latter species is a complex taxon comprising several pathovars as well as nonpathogenic, environmental, and, in some cases, clinical species (Francis et al. 2011). Among the gram-positive bacterial plant pathogens, C. flaccumfaciens is the least-studied member in terms of genomic features and pathogenicity determinants (Chen et al. 2021; Thapa et al. 2019). Plant-pathogenic members of $C$. flaccumfaciens are subdivided into five pathovars based on their host of isolation, pathogenicity, and host range (Collins and Jones 1983; Davis and Vidaver 2001; Davis 1986, 2001). Pathovars of the species include C. flaccumfaciens pv. flaccumfaciens, causing bacterial wilt of dry beans (Hedges 1922), C. flaccumfaciens pv. poinsettiae,

${ }^{\dagger}$ Corresponding authors: E. Osdaghi; eosdaghi@ut.ac.ir, P. Portier; perrine.portier@inrae.fr, and M.-A. Jacques; marie-agnes.jacques@inrae.fr

The author(s) declare no conflict of interest.

Accepted for publication 10 January 2022.

\section{Funding}

These genomes were sequenced as a part of the Institut National de la Recherche Agronomique DISC/CNOC (INRAE) CIRM 2020 strain sequencing project. The work of $E$. Osdaghi was funded by the College of Agriculture Natural Resources, University of Tehran. Authors benefited from interactions promoted by COST Action CA16107.

\section{Keywords}

actinobacteria, bacterial wilt of beans, coryneform bacteria,

Microbacteriaceae, quarantine pathogen, bacterial pathogenesis 
Table 1. Source, place, and date of isolation, and genomic information of the Curtobacterium flaccumfaciens strains used in this study

\begin{tabular}{|c|c|c|c|c|c|c|c|}
\hline Strain & Other names & Taxon & Host & Year & Country & $\begin{array}{c}\text { Colony } \\
\text { color } \\
\text { (pigmentation) }\end{array}$ & $\begin{array}{c}\text { Genome } \\
\text { size } \\
\text { (bp) }\end{array}$ \\
\hline CFBP $2402^{P T}$ & $\begin{array}{l}\text { ICMP } 2594^{\mathrm{PT}}, \mathrm{LMG} \\
3596^{\mathrm{PT}}, \mathrm{NCPPB} 374^{\mathrm{PT}}\end{array}$ & $\begin{array}{l}\text { C. flaccumfaciens } \\
\text { pv. betae }\end{array}$ & Beta vulgaris & 1955 & U.K. & Yellow-Dry & $3,768,077$ \\
\hline CFBP $1384^{\mathrm{PT}}$ & $\begin{array}{l}\text { NCPPB } 2113^{\mathrm{PT}}, \text { ATCC } \\
25283^{\mathrm{PT}}, \text { ICMP }^{2} 632^{\mathrm{PT}}, \\
\text { LMG } 3702^{\mathrm{PT}}\end{array}$ & $\begin{array}{l}\text { C. flaccumfaciens } \\
\text { pv. oortii }\end{array}$ & $\begin{array}{l}\text { Tulipa } \\
\quad \text { gesneriana }\end{array}$ & 1967 & Netherlands & Yellow-Fluidal & $4,024,422$ \\
\hline CFBP $2403^{\mathrm{PT}}$ & $\begin{array}{l}\text { ICMP } 2566^{\mathrm{PT}}, \text { ATCC } \\
9682^{\mathrm{PT}}, \text { NCPPB } 854^{\mathrm{PT}}\end{array}$ & $\begin{array}{l}\text { C. flaccumfaciens } \\
\text { pv. poinsettiae }\end{array}$ & $\begin{array}{l}\text { Euphorbia } \\
\text { pulcherrima }\end{array}$ & Missing & U.S.A. & Orange-Dry & $3,616,077$ \\
\hline CFBP 3400 & PD 1751 & $\begin{array}{l}\text { C. flaccumfaciens } \\
\text { pv. oortii }\end{array}$ & $\begin{array}{l}\text { Zantedeschia } \\
\text { aethiopica }\end{array}$ & 1990 & Netherlands & Yellow-Dry & $3,773,592$ \\
\hline CFBP 3423 & $\begin{array}{l}\text { NCPPB 2344, ATCC } \\
23827\end{array}$ & $\begin{array}{l}\text { C. flaccumfaciens } \\
\text { pv. flaccumfaciens }\end{array}$ & $\begin{array}{l}\text { Phaseolus } \\
\text { vulgaris }\end{array}$ & 1957 & U.S.A. & Yellow-Fluidal & $3,906,894$ \\
\hline CFBP 3422 & $\begin{array}{l}\text { NCPPB 2343, ATCC } \\
12813\end{array}$ & $\begin{array}{l}\text { C. flaccumfaciens } \\
\text { pv. flaccumfaciens }\end{array}$ & $\begin{array}{r}\text { Phaseolus } \\
\text { vulgaris }\end{array}$ & 1956 & U.S.A. & Orange-Dry & $3,587,123$ \\
\hline CFBP 3417 & NCPPB 558 & $\begin{array}{l}\text { C. flaccumfaciens } \\
\text { pv. flaccumfaciens }\end{array}$ & $\begin{array}{l}\text { Phaseolus } \\
\text { vulgaris }\end{array}$ & 1958 & U.S.A. & Orange-Fluidal & $3,731,936$ \\
\hline CFBP 3401 & LMG 7238, PDDCC 4735 & $\begin{array}{l}\text { C. flaccumfaciens } \\
\text { pv. betae }\end{array}$ & Beta vulgaris & Missing & U.K. & Yellow-Dry & $3,771,893$ \\
\hline CFBP 3415 & LMG 7321 & $\begin{array}{l}\text { C. flaccumfaciens } \\
\text { pv. poinsettiae }\end{array}$ & $\begin{array}{l}\text { Euphorbia } \\
\text { pulcherrima }\end{array}$ & Missing & U.S.A. & Orange-Fluidal & $3,693,818$ \\
\hline CFBP 8818 & Tom50, ICMP 22062 & $\begin{array}{l}\text { C. flaccumfaciens } \\
\text { pv. flaccumfaciens }\end{array}$ & $\begin{array}{l}\text { Solanum } \\
\quad \text { lycopersicum }\end{array}$ & 2015 & Iran & Red-Dry & $3,718,276$ \\
\hline CFBP 8819 & 50R, ICMP 22071 & $\begin{array}{l}\text { C. flaccumfaciens } \\
\text { pv. flaccumfaciens }\end{array}$ & $\begin{array}{l}\text { Phaseolus } \\
\text { vulgaris }\end{array}$ & 2014 & Iran & Red-Fluidal & $3,722,562$ \\
\hline CFBP 8820 & P990, ICMP 22053 & $\begin{array}{l}\text { C. flaccumfaciens } \\
\text { pv. flaccumfaciens }\end{array}$ & $\begin{array}{l}\text { Capsicum } \\
\text { annuum }\end{array}$ & 2015 & Iran & Yellow-Fluidal & $3,841,555$ \\
\hline CFBP 8821 & Cmmeg20, ICMP 22056 & C. flaccumfaciens & $\begin{array}{l}\text { Solanum } \\
\quad \text { melongena }\end{array}$ & 2014 & Iran & Yellow-Fluidal & $3,667,557$ \\
\hline CFBP 8822 & Xeu15, ICMP 21400 & C. flaccumfaciens & $\begin{array}{l}\text { Capsicum } \\
\text { annuum }\end{array}$ & 2013 & Iran & Yellow-Fluidal & $3,715,976$ \\
\hline CFBP 8823 & Cff156 & $\begin{array}{l}\text { C. flaccumfaciens } \\
\text { pv. flaccumfaciens }\end{array}$ & $\begin{array}{c}\text { Phaseolus } \\
\text { vulgaris }\end{array}$ & 2015 & Iran & Orange-Fluidal & $3,749,403$ \\
\hline CFBP 8824 & G105, ICMP 22064 & C. flaccumfaciens & $\begin{array}{l}\text { Solanum } \\
\quad \text { lycopersicum }\end{array}$ & 2015 & Iran & Red-Fluidal & $3,603,541$ \\
\hline CFBP 8825 & Tom827, ICMP 22084 & C. flaccumfaciens & $\begin{array}{l}\text { Solanum } \\
\quad \text { lycopersicum }\end{array}$ & 2015 & Iran & $\begin{array}{l}\text { Yellow-Fluidal } \\
\text { (Continued on } n\end{array}$ & next page) \\
\hline
\end{tabular}

\footnotetext{
${ }^{\mathrm{a}} \mathrm{CDS}=$ coding sequences.

b Presence of plasmids was evaluated using both PlasmidFinder and SourceFinder services, while the presence of phages was evaluated using SourceFinder. ND = Not detected.

${ }^{c}$ The numbers indicate the contig number in the FASTA files (in the GenBank database) in which the corresponding sequence was detected.
}

causing bacterial canker of poinsettia (Pirone and Bender 1941), C. flaccumfaciens pv. betae, the agent of silvering disease of red beet (Keyworth et al. 1956), C. flaccumfaciens pv. ilicis, causing bacterial blight of American holly (Mandel et al. 1961; Young et al. 2004), and C. flaccumfaciens pv. oortii, the agent of bacterial wilt and spot of tulip (Saaltink and Maas Geesteranus 1969). Two additional pathovars including 'C. flaccumfaciens pv. basellae', the causal agent of bacterial leaf spot of malabar spinach (Basella alba or B. ruba) (Chen et al. 2000), and 'C. flaccumfaciens pv. beticola', the causal agent of bacterial leaf spot of sugar beet (Chen et al. 2007) were also proposed. However, the Committee on the Taxonomy of Plant Pathogenic bacteria (Bull et al. 2010) has not accepted them to date as valid taxa.

Among these pathovars, bacterial wilt of dry beans caused by $C$. flaccumfaciens pv. flaccumfaciens and bacterial canker of poinsettia caused by $C$. flaccumfaciens pv. poinsettiae are economically important, the former one being included as a quarantine pathogen in the Annex II part A of European Regulation 2019/2072 and in the A2 list of the European and Mediterranean Plant Protection Organization and the latter one being included in the alert lists of EPPO (EPPO 2011; Osdaghi et al. 2020a). While molecular diagnostic tests are available to detect and identify C. flaccumfaciens pv. flaccumfaciens 
Table 1. (Continued from previous page)

\begin{tabular}{|c|c|c|c|c|c|c|c|c|}
\hline \multirow{2}{*}{\multicolumn{3}{|c|}{ No. of }} & \multirow{3}{*}{$\begin{array}{c}\mathrm{G}+\mathrm{C} \% \\
\text { content }\end{array}$} & \multirow{3}{*}{$\underset{\times}{\text { Coverage }}$} & \multicolumn{3}{|c|}{ Plasmid/phage $^{\text {b }}$} & \multirow{3}{*}{$\begin{array}{c}\text { GenBank } \\
\text { accession } \\
\text { number }\end{array}$} \\
\hline & & & & & \multirow{2}{*}{$\begin{array}{l}\text { Plasmid } \\
\text { Finder }\end{array}$} & \multicolumn{2}{|l|}{ SourceFinder } & \\
\hline $\mathrm{CDSs}^{\mathrm{a}}$ & Genes & Contigs & & & & Phage $^{c}$ & Plasmid & \\
\hline 3,534 & 3,589 & 50 & 70.9 & 219 & ND & $45,49,50$ & ND & JAHEXD000000000 \\
\hline 3,821 & 3,878 & 64 & 70.7 & 249 & ND & $7,54,59,61,63,64$ & ND & JAHEXC000000000 \\
\hline 3,396 & 3,450 & 54 & 71.0 & 219 & ND & 39,53 & ND & JAHEXB000000000 \\
\hline 3,559 & 3,614 & 48 & 71.0 & 249 & ND & ND & ND & JAHEXA000000000 \\
\hline 3,682 & 3,739 & 52 & 70.5 & 204 & ND & $25,41,43,46,51,52$ & $\begin{array}{c}40,44 \\
45\end{array}$ & JAHEWZ000000000 \\
\hline 3,349 & 3,404 & 45 & 71.0 & 234 & ND & 2,44 & ND & JAHEWY000000000 \\
\hline 3,549 & 3,604 & 48 & 70.8 & 264 & ND & $15,22,40,46,47,48$ & 36 & JAHEWX000000000 \\
\hline 3,540 & 3,595 & 52 & 70.9 & 310 & ND & $\begin{array}{c}9,17,19,40,42,43,46,47,48,49 \\
50\end{array}$ & ND & JAHEWW000000000 \\
\hline 3,464 & 3,518 & 43 & 70.9 & 332 & ND & $40,42,43$ & ND & JAHEWU000000000 \\
\hline 3,497 & 3,553 & 73 & 70.9 & 189 & ND & $19,56,59,63,67$ & ND & JAHEWT000000000 \\
\hline 3,504 & 3,556 & 63 & 70.8 & 219 & ND & $24,44,48,53,57,60$ & ND & JAHEWS000000000 \\
\hline 3,618 & 3,673 & 56 & 70.9 & 234 & ND & $24,52,55,56$ & ND & JAHEWR000000000 \\
\hline 3,417 & 3,470 & 47 & 71.0 & 189 & ND & 46,47 & ND & JAHEWQ000000000 \\
\hline 3,495 & 3,549 & 47 & 71.0 & 219 & ND & 46,47 & ND & JAHEWP000000000 \\
\hline 3,519 & 3,576 & 65 & 70.8 & 227 & ND & $12,23,53,56,59,64$ & ND & JAHEWO000000000 \\
\hline 3,369 & 3,422 & 35 & 71.0 & 287 & ND & $8,33,35$ & ND & JAHEWN000000000 \\
\hline 3,487 & 3,542 & 47 & 71.0 & 189 & ND & $25,45,46$ & ND & JAHEWM000000000 \\
\hline
\end{tabular}

(Tegli et al. 2020), quarantined members of the species require considerable cost and effort to prevent the risk of global spread and introduction into areas yet free of the disease (Harveson et al. 2015; Osdaghi et al. 2020a). Members of $C$. flaccumfaciens are well-known for variability in colony pigmentation and morphology possessing a wide range of colony variants including orange, pink, purple, red, and yellow phenotypes in either fluidal, mucoid, or dry form on culture media (Harveson and Vidaver 2008; Osdaghi and Lak 2015; Osdaghi et al. 2016). As a complex species, population structure and taxonomy of $C$. flaccumfaciens has rarely been examined using high throughput genomics techniques, leaving the phylogenetic relationships of different pathovars to each other uninvestigated. Further, due to the lack of whole-genome resources from different pathovars of $C$. flaccumfaciens, pathogenicity-associated genomic features and virulence strategies of its members are still almost entirely unknown. Unlike the other plant-pathogenic actinobacteria, for which the nucleotide sequence data from a wide range of strains are available (Ansari et al. 2019; Jacques et al. 2012; Osdaghi et al. 2020b), whole-genome sequence data of only a few $C$. flaccumfaciens strains are published in the literature (Chen et al. 2021). Among the pathotype strains of the species, C. flaccumfaciens pv. flaccumfaciens is the only one for which a whole-genome sequence is available (Gonçalves et al. 2019).

DNA fingerprinting-based investigations (Agarkova et al. 2012; Osdaghi et al. 2018a) and multilocus sequence analysis (MLSA) (Gonçalves et al. 2019: Osdaghi et al. 2018b) suggested high genetic diversity among plant pathogenic members of $C$. flaccumfaciens either in an intrapathovar or interpathovar level. For instance, it has been noted that yellow-pigmented 
strains of the dry bean pathogen C. flaccumfaciens pv. flaccumfaciens are genetically and phylogenetically distinct from those of red- and orange-pigmented strains of the same pathovar (Osdaghi et al. 2018a, b). Interestingly, MLSA-based results showed that the red- and orangepigmented strains of the latter pathogen are phylogenetically more related to the poinsettia pathogen $C$. flaccumfaciens pv. poinsettiae than to the pathotype strain of $C$. flaccumfaciens pv. flaccumfaciens. All these findings led us to conclude that an inclusive genome sequencing effort is warranted to shed light on the taxonomic structure, phylogenetic relationships, and genomic repertoires of $C$. flaccumfaciens members. Thus, the main objective of this study was to provide whole-genome resources for $17 \mathrm{C}$. flaccumfaciens strains, covering nearly the entire genetic diversity of the species, including the pathotype strains of $C$. flaccumfaciens pv. betae, C. flaccumfaciens pv. oortii, and C. flaccumfaciens pv. poinsettiae.

C. flaccumfaciens strains representing members of different pathovars with various colony morphology (pigmentation) and diverse geographic origins were obtained from the French Collection for Plant-Associated Bacteria CIRM-CFBP (Table 1). The strains were streaked onto yeast-extract peptone glucose agar medium, were resuspended in sterile distilled water and stored at $4^{\circ} \mathrm{C}$ for further use, and were stored in $15 \%$ glycerol at $-70^{\circ} \mathrm{C}$ for long-term purposes. Bacterial DNAs were extracted using the Wizard genomic DNA purification kit (Promega, Madison WI, U.S.A.). The 17 strains were sequenced using NovaSeq 6000 Illumina with Nextera XT Preparation kit and paired-end 150 bp (Institut du Cerveau, CHU Pitié-Salpêtrière, Paris). Genome assembly was performed using SPAdes 1 (Bankevich et al. 2012) after a quality filtration with CheckM (Parks et al. 2015). For each strain, sequencing coverage, genome size, number of contigs, and $\mathrm{G}+\mathrm{C}$ percentage are summarized in Table 1. Genome annotation was performed using the GeneMarkS+ suite implemented in the National Center for Biotechnology Information (NCBI) Prokaryotic Genome Annotation Pipeline with default settings (Borodovsky and Lomsadze 2014). Total number of genes and coding sequences were determined for all the genomes (Table 1).

Whole-genome sequences of the $17 \mathrm{C}$. flaccumfaciens strains obtained in this study were assembled in contigs varying in number from 35 to 73 , while sequencing coverage was between 189x and 332x (Table 1). Genome size of the strains ranged from 3,587,123 bp in C. flaccumfaciens pv. flaccumfaciens CFBP 3422 to $4,024,422$ bp in the pathotype strain of C. flaccumfaciens pv. oortii CFBP $1384^{\mathrm{PT}}$, while $\mathrm{G}+\mathrm{C} \%$ content was between 70.5 and $71.0 \%$ (Table 1). It has previously been shown that a number of $C$. flaccumfaciens strains possess plasmids harboring various biological functions (Chen et al. 2021; Hendrick et al. 1984; Vaghefi et al. 2021). Hence, the genome sequences obtained in this study were investigated for the presence of plasmid and phage sequences via online services PlasmidFinder 2.0 and SourceFinder 1.0 (Carattoli et al. 2014). While PlasmidFinder did not find any plasmid in the genome sequences, SourceFinder suggested the presence of plasmid in the C. flaccumfaciens pv. flaccumfaciens strains CFBP 3423 and CFBP 3417 . Phage fragments were also frequently detected in all the genomes except C. flaccumfaciens pv. oortii CFBP 3400 , as detailed in Table 1. Agarose gel-based plasmid profiling is recommended to decipher the precise plasmid profile of the strains sequenced in this study. Furthermore, a preliminary average nucleotide identity (ANI) and digital DNA-DNA hybridization calculation among the strains sequenced in this study suggest a need for an in-depth taxonomic investigation on the phylogenetic relationships of the $C$. flaccumfaciens members. For instance, ANI between the type strain of $C$. flaccumfaciens CFBP $3418^{\top}$ and the pathotype strain of $C$. flaccumfaciens pv. poinsettiae CFBP $2403 \mathrm{P}^{\top}$ was $93.5 \%$, which was below the accepted threshold (95 to $96 \%$ ) for definition of prokaryotic species (Kim et al. 2014). A comprehensive multiphasic taxonomic study is ongoing to re-evaluate the taxonomy of $C$. flaccumfaciens complex species.

\section{Data Availability}

The whole-genome shotgun sequences obtained in this study are deposited at the NCBI GenBank database under the accession numbers shown in Table 1. Furthermore, a pure culture of the 17 strains is available in CIRM-CFBP culture collection.

\section{Acknowledgments}

We thank C. Dutrieux and A. Lathus at CIRM-CFBP for preservation of the bacterial strains. 


\section{Literature Cited}

Agarkova, I. V., Lambrecht, P. A., Vidaver, A. K., and Harveson, R. M. 2012. Genetic diversity among Curtobacterium flaccumfaciens pv. flaccumfaciens populations in the American high plains. Can. J. Microbiol. 58:788-801.

Ansari, M., Taghavi, S. M., Hamzehzarghani, H., Valenzuela, M., Siri, M. I., and Osdaghi, E. 2019. Multiple introductions of tomato pathogen Clavibacter michiganensis subsp. michiganensis into Iran as revealed by a global-scale phylogeographic analysis. Appl. Environ. Microbiol. 85:e02098-e2119.

Bankevich, A., Nurk, S., Antipov, D., Gurevich, A. A., Dvorkin, M., Kulikov, A. S., Lesin, V. M., Nikolenko, S. I., Pham, S., Prjibelski, A. D., Pyshkin, A. V., Sirotkin, A. V., Vyahhi, N., Tesler, G., Alekseyev, M. A., and Pevzner, P. A 2012. SPAdes: A new genome assembly algorithm and its applications to single-cell sequencing. J. Comput. Biol. 19:455-477.

Borodovsky, M., and Lomsadze, A. 2014. Gene identification in prokaryotic genomes, phages, metagenomes, and EST sequences with GeneMarkS suite. Curr. Protoc. Microbiol. 32:7.

Bull, C. T., De Boer, S. H., Denny, T. P., Firrao, G., Fischer-Le Saux, M., Saddler, G. S., Scortichini, M., Stead, D. E., and Takikawa, Y. 2010. Comprehensive list of plant pathogenic bacteria 1980-2007. J. Plant Pathol. 92:551-592.

Carattoli, A., Zankari, E., García-Fernández, A., Voldby Larsen, M., Lund, O., Villa, L., Møller Aarestrup, F., and Hasman, H. 2014. In silico detection and typing of plasmids using PlasmidFinder and plasmid multilocus sequence typing. Antimicrob. Agents Chemother. 58:3895-3903.

Chen, G., Khojasteh, M., Taheri-Dehkordi, A., Taghavi, S. M., Rahimi, T., and Osdaghi, E. 2021. Complete genome sequencing provides novel insight into the virulence repertories and phylogenetic position of dry beans pathogen Curtobacterium flaccumfaciens pv. flaccumfaciens. Phytopathology 111:268-280.

Chen, Y. F., Guo, J. H., and Fang, Z. D. 2000. A new pathovar of Curtobacterium flaccumfaciens on malabar spinach. Acta Phytopathologica Sin. 30:171-175.

Chen, Y. F., Yin, Y. N., Zhang, X. M., and Guo, J. H. 2007. Curtobacterium flaccumfaciens pv. beticola, a new pathovar of pathogens in sugar beet. Plant Dis. 91:677-684.

Collins, M. D., and Jones, D. 1983. Reclassification of Corynebacterium flaccumfaciens, Corynebacterium betae, Corynebacterium oortii and Corynebacterium poinsettiae in the genus Curtobacterium, as Curtobacterium flaccumfaciens comb. nov. J. Gen. Microbiol. 129:3545-3548.

Davis, M. J. 1986. Taxonomy of plant-pathogenic coryneform bacteria. Annu. Rev. Phytopathol. 24:115-140.

Davis, M. J. 2001. Coryneform phytobacteria. Pages 255-256 in: Encyclopdia of Plant Pathology. Vol. 1. O. C. Maloy, and T. D. Murray, eds. John Wiley and sons, Inc., New York.

Davis, M. J., and Vidaver, A. K. 2001. Coryneform plant pathogens. Pages 218-235 in: Laboratory Guide for Identification of Plant Pathogenic Bacteria, 3rd Ed., N. W. Schaad, J. B. Jones, and W. Chun, eds. APS Press, St. Paul, MN, U.S.A.

Dye, D. W., and Kemp, W. J. 1977. A taxonomic study of plant pathogenic Corynebacterium species. New Zeal. J. Agr. Res. 20:563-582.

EPPO. 2011. Curtobacterium flaccumfaciens pv. flaccumfaciens. Bulletin OEPP/ EPPO Bulletin 41:320-328

Francis, M. J., Doherty, R. R., Patel, M., Hamblin, J. F., Ojaimi, S., and Korman, T. M. 2011. Curtobacterium flaccumfaciens septic arthritis following puncture with a Coxspur Hawthorn thorn. J. Clin. Microbiol. 49:2759-2760.

Gonçalves, R. M., Balbi-Peña, M. I., Soman, J. M., Maringoni, A. C., Taghouti, G., Fischer-Le Saux, M., and Portier, P. 2019. Genetic diversity of Curtobacterium flaccumfaciens revealed by multilocus sequence analysis. Eur. J. Plant Pathol. 154:189-202.

Harveson, R. M., Schwartz, H. F., Urrea, C. A., and Yonts, C. D. 2015. Bacterial wilt of dry-edible beans in the central high plains of the U.S.: Past, present, and future. Plant Dis. 99:1665-1677.

Harveson, R. M., and Vidaver, A. K. 2008. A new color variant of the dry bean bacterial wilt pathogen (Curtobacterium flaccumfaciens pv. flaccumfaciens) found in western Nebraska. Plant Health Prog. 9:43.

Hedges, F. 1922. A bacterial wilt of the bean caused by Bacterium flaccumfaciens nov. sp. Science 55:433-434
Hendrick, C. A., Haskins, W. P., and Vidaver, A. K. 1984. Conjugative plasmid in Corynebacterium flaccumfaciens subsp. oortii that confers resistance to arsenite, arsenate, and antimony(III). Appl. Environ. Microbiol. 48:56-60.

Jacques, M. A., Durand, K., Orgeur, G., Balidas, S., Fricot, C., Bonneau, S., Quillévéré, A., Audusseau, C., Olivier, V., Grimault, V., and Mathis, R. 2012. Phylogenetic analysis and polyphasic characterization of Clavibacter michiganensis strains isolated from tomato seeds reveal that nonpathogenic strains are distinct from $C$. michiganensis subsp. michiganensis. Appl. Environ. Microbiol. 78:8388-8402.

Keyworth, W. G., Howell, J., and Dowson, W. J. 1956. Corynebacterium betae (sp. nov.) The causal organism of silvering disease of red beet. Plant Pathol. 5:88-90.

Kim, M., Oh, H. S., Park, S. C., and Chun, J. 2014. Towards a taxonomic coherence between average nucleotide identity and $16 \mathrm{~S}$ rRNA gene sequence similarity for species demarcation of prokaryotes. Int. J. Syst. Evol. Microbiol. 64:346-351.

Mandel, M., Guba, E. F., and Litsky, W. 1961. The causal agent of bacterial blight of American holly. Bacteriological Proceedings 61:61.

Osdaghi, E., and Lak, M. R. 2015. Occurrence of a new orange variant of Curtobacterium flaccumfaciens pv. flaccumfaciens, causing common bean wilt in Iran. J. Phytopathol. 163:867-871.

Osdaghi, E., Rahimi, T., Taghavi, S. M., Ansari, M., Zarei, S., Portier, P., Briand, M., and Jacques, M. A. 2020b. Comparative genomics and phylogenetic analyses suggest several novel species within the genus Clavibacter, including nonpathogenic tomato-associated strains. Appl. Environ. Microbiol. 86:e02873-19.

Osdaghi, E., Taghavi, S. M., Calamai, S., Biancalani, C., Cerboneschi, M., Tegli, S., and Harveson, R. M. 2018b. Phenotypic and molecular-phylogenetic analysis provide novel insights into the diversity of Curtobacterium flaccumfaciens. Phytopathology 108:1154-1164.

Osdaghi, E., Taghavi, S. M., Hamzehzarghani, H., Fazliarab, A., Harveson, R. M., and Lamichhane, J. R. 2016. Occurrence and characterization of a new redpigmented variant of Curtobacterium flaccumfaciens, the causal agent of bacterial wilt of edible dry beans in Iran. Eur. J. Plant Pathol. 146:129-145.

Osdaghi, E., Taghavi, S. M., Hamzehzarghani, H., Fazliarab, A., Harveson, R. M., Tegli, S., and Lamichhane, J. R. 2018a. Epiphytic Curtobacterium flaccumfaciens strains isolated from symptomless solanaceous vegetables are pathogenic on leguminous but not on solanaceous plants. Plant Pathol. 67:388-398.

Osdaghi, E., Young, A. J., and Harveson, R. M. 2020a. Bacterial wilt of dry beans caused by Curtobacterium flaccumfaciens pv. flaccumfaciens: A new threat from an old enemy. Mol. Plant Pathol. 21:605-621.

Parks, D. H., Imelfort, M., Skennerton, C. T., Hugenholtz, P., and Tyson, G. W. 2015. CheckM: Assessing the quality of microbial genomes recovered from isolates, single cells, and metagenomes. Genome Res. 25:1043-1055.

Pirone, P. P., and Bender, T. R. 1941. A new bacterial disease of poinsettiae. New Jersey Agriculture and experimental Nursery Disease Notes 14:13-16.

Saaltink, G., and Maas Geesteranus, H. P. 1969. A new disease of tulip caused by Corynebacterium oortii nov. sp. Neth. J. Plant Pathol. 75:123-128.

Tegli, S., Biancalani, C., Ignatov, A. N., and Osdaghi, E. 2020. A powerful LAMP weapon against the threat of the quarantine plant pathogen Curtobacterium flaccumfaciens pv. flaccumfaciens. Microorganisms 8:1705.

Thapa, S. P., Davis, E. W., 2nd, Lyu, Q., Weisberg, A. J., Stevens, D. M., Clarke, C. R., Coaker, G., and Chang, J. H. 2019. The evolution, ecology, and mechanisms of infection by gram-positive, plant-associated bacteria. Annu. Rev. Phytopathol. 57:341-365.

Vaghefi, N., Adorada, D. L., Huth, L., Kelly, L. A., Poudel, B., Young, A., and Sparks, A. H. 2021. Whole-genome data from Curtobacterium flaccumfaciens pv. flaccumfaciens strains associated with tan spot of mungbean and soybean reveal diverse plasmid profiles. Mol. Plant-Microbe Interact. 34:1216-1222.

Vidaver, A. K., and Davis, M. J. 1988. Coryneform plant pathogens. Pages 104113 in: Laboratory Guide for Identification of Plant Pathogenic Bacteria, 2nd ed. N. W. Schaad, ed. APS Press, St. Paul, MN, U.S.A.

Young, J. M., Watson, D. R. W., and Dye, D. W. 2004. Reconsideration of Arthrobacter ilicis (Mandel et al. 1961) Collins et al. 1982 as a plantpathogenic species. Proposal to emend the authority and description of the species. Request for an opinion. Int. J. Syst. Evol. Microbiol. 54:303-305. 